\title{
Using of Archives in Scientific Purposes: the Archives of Yugoslavia
}

\author{
BRANKa DOKNIC, PH.D.
}

The Arhives of Yugoslavia, Vase Pelagića 33, Beograd.

email: branka.doknic@arhivyu.rs

Using of Archives in Scientific Purposes: the Archives of Yugoslavia

\section{ABSTRACT}

Archival documentation of the central state authorities is according to its categorization the first class historic source and as such inevitable in scientific research of historic time that it refers to. The Archives of Yugoslavia, former state archive and today common cultural heritage is unavoidable spot for various researchers. For the purpose of qualitative appraisal, categorization, research work and publishing of cultural heritage entrusted to the Archives of Yugoslavia, establishment of scientific department is necessary. This department will essentially contribute to the improvement of complete archival activity.

Key words: archival document, historic source, scientific research, scientific department, The Archives of Yugoslavia

\section{L'utilizzo degli archivi per fini scientifici: l'Archivio di Jugoslavia}

\section{SINTESI}

La documentazione archivistica delle autorità dello Stato centrale secondo la sua categorizzazione è la fonte storica di prima classe ed in quanto tale è inevitabile la sua consultazione volendo fare ricerca storico-scientifica. L'Archivio di Jugoslavia, un tempo Archivio di Stato ed oggi comune patrimonio culturale, sono ineludibili punti di partenza per le più svariate ricerche. Allo scopo di una valorizzazione qualitativa, categorizzante, di lavoro di ricerca e pubblicazione del patrimonio culturale conservato nell'Archivio di Jugoslavia è necessario costituire un dipartimento scientifico che possa contribuire allo sviluppo di una completa attività archivistica.

Parole chiave: documento archivistico, fonte storica, ricerca scientifica, dipartimento scientifico, Archivio di Jugoslavia

Uporaba arhivskega gradiva za znanstvene namene: Arhiv Jugoslavije

\section{IZVLEČEK}

Arhivski dokumenti osrednjih organov so prvovrstni zgodovinski viri in kot takšni nepogrešljivi na področju znanstvenih raziskav za čas, na katerega se nanašajo. Arhiv Jugoslavije, nekdanji Državni arhiv, danes pa skupna kulturna dediščina, je edinstven kraj za številne raziskovalce. V interesu kakovosti valorizacije, kategorizacije, raziskav in objavljanja $\mathrm{v}$ varstvo zaupane dediščina, je $\mathrm{v}$ arhivu potrebno ustanoviti poseben znanstveni oddelek. Takšen oddelek bi bistveno prispeval k izboljšanju celotne arhivske dejavnosti.

Ključne besede: arhivski dokumenti, zgodovinski viri, znanstvene raziskave, znanstveni oddelek, Arhiv Jugoslavije

Korišćenje arhiva u naučne svrhe: Arhiv Jugoslavije

Apstrakt

Arhivski dokumenti centralnih državnih organa su po svojoj kategorizaciji prvorazredni istorijski izvori i kao takvi nezaobilazni u naučnom istraživanju istorijskog vremena na koji se odnose. Arhiv Jugoslavije, nekadašnji državni arhiv, a danas zajednička kulturna baština je jedinstveno mesto mnogobrojnih istraživača. U interesu kvalitetne valorizacije, kategorizacije, istraživanja i publikovanja poverene mu kulturne baštine u Arhivu Jugoslavije je neophodno formiranje naučnog odeljenja. Takvo odeljenje bi suštinski doprinelo unapređenju ukupne arhivske delatnosti.

Ključne reči: Arhivski dokument, istorijski izvor, naučno istraživanje, naučno odeljenje, Arhiv Jugoslavije 


\section{About history and archival document}

History is the most dangerous product evolved from the chemistry of intellect, Paul Valery said and added that characteristic of history is to provoke dreams, intoxicate nations, accumulate bad memories, exaggerate their complexes, injure old wounds, make nations bitter, arrogant and vain, justifying those things they want (Ilic 1974, pp. 129-130). That is the reason why the archives being the institutions that preserve the closest truth about the past times are so important to every country and that is the reason why after 220 years of their existence their status haven't been defined properly yet. The Archives shouldn't be places for storing the past but places where we study about the past today for the purpose of the future. Status that the archives have within public cultural scene in one country tells much about the democracy of that country. Non democratic approach of the system towards archival documentation as historic source proves itself in two ways - whether by complete lack of concern for collecting and preserving or opposite by extreme attention, being highly protected, separated from the public, especially scientific public. Not a single country no matter how democratic it is does allow inspection of its past, but the process of liberalization in this field is gradual and constant ${ }^{1}$. Accessibility of archival material first of all in scientific purposes but for other purposes as well becomes dominant request of scientific public. Neglecting and not solving the status of the archival material preserved in the archival depots is not as it used to be from ideological - political reasons but more from intellectual and financial irresponsibility towards cultural heritage. The problem becomes even bigger since the definition of the archival material has been changed. For one century ago only documents presenting so called "guillotine" history respectfully the history of crowned heads and war conflicts were preserved, modern archives today collect archival material of complete social history with the same respect ${ }^{2}$. Increased volume of documents that have been preserved becomes more dominant problem by the time for unhindered access to the archival material.

Work experience with archival material contributes to dual approach to this significant historic source - not a single proper historic research could be performed without access to the archival documentation, but on the other hand for that same historical source applies determinant that strictly speaking does not teach anything since it has everything and gives example for everything. Besides, Immensity of raw archival material without knowing the essence of research of the historic epoch could deceive, tire and mislead the researcher. It could be mentioned also that the same words could make various texts. Archival document as historical source has its peculiarity in scientific research compared to other historical sources. Different from the writer of the book person who creates archival document said Blake and Macraild "didn't have any intention to prove anything (although it is possible). Original text does not address historians - different from a book, it does not want to convince anybody to anything". In order that one who reads the archival document understands its meaning, one should have in front of oneself letter or court report and should during reading answer some questions:

1. Who is the author of a document

2. Why was that document written and for what purpose

3. What is historical context of that document (e.g. republican or democratic government in wartime or peace...etc.)

4. What was the purpose of a document

5. To whom was the document assigned (Blejk and Makrejld 2007, p. 223).

The answer to those questions will reveal significance of the content of individual archival document and possibility to use it as reliable historical source.

Complete European strategy of cultural politic at the beginning of 21 st century is based on research founded on facts on expertize, evaluation, statistic indexes, respectfully on terms that perform

1. That is the reason why the International Council of Archives intervenes and its recommendations that almost all world archives obey having in mind number of 160 members.

2. "While researching human activities, the matter of decision what is significant and what will be more important in the future is very important. I know when the State Archives was founded in this country that it was flooded by documents so that people that were engaged to work there said that had a problem storing all those documents...I heard that on that occasion all public and private documents dealing with construction of railway in England were destroyed and the excuse was that that subject was boring and was not of any interest to anyone. Can you image what would economist do today if only they could have those documents?" (Tojnbi, 2002, p. 548). 
scientific politics. That's why modern archive being part of cultural heritage according to its new definition presents part of scientific field. Although the archive is not institution which primary activity is scientific research, in past decades part of the activity of the archive has been work that is done between profession and science, so that in modern world archives, there are those between the employees who deal with scientific research work. For the purpose of necessary changes that would develop work of the archives, it is necessary to have professional staff that would deal with scientific work. This category of employees has become necessary "since no critical opinion of someone else's scientific work is possible if one that criticizes is not able to treat scientific problems from the archival documentation by oneself and to refer competently to someone else's work" (Milošević 1986, pp. 207-209). Insisting on employing gifted students who will not reconcile with dealing exclusively with technical matters referred to archival material, without possibility to have creative approach if they are interested in that, started at the eighties of the last century being the manner how to develop Yugoslav archival institutions. Scientific departments use to be a practice for almost a century in the world bigger archive. Modern archive is not valid without scientific researchers, because only this type or archivists could be a real help to the researchers, inevitable in valorization of archival documents and unavoidable in writing scientific finding aids but the only one "who could be qualified to analyze different use and misuse of archival material" (Ibidem). Scientific work in archives should deal with fonds that are in the archives and with history of institutions who store the fonds since only then scientific work could be in favor of professional archive work. As the goal of modern scientific strategy is collecting, describing, classifying, defying, generalizing, explaining, forecasting and evaluating, so manner of work with historic document in modern archival institution makes archival institution part of scientific practice (Sesic and Stojkovic 2011, p. 324). Status of the archive as scientific institution is especially important with so called "dead archives" as it is the Archives of Yugoslavia since in those institutions, basic activity is scientific valorization of the archival material and its publishing for scientific purposes. The Archive that on its list of jobs has scientific research as well will be a complete archive and its establishing will lead to existential progress in complete archival profession.

\section{Historic sources in the archives of Yugoslavia and possibilities for research work}

The Archives of Yugoslavia has been member of ICA from its foundation, first as the state archive and today as the archive that preserves cultural heritage of all former republics of Yugoslav Federation. Starting modest with incomplete fonds of the institutions of the Kingdom of Yugoslavia and fonds of the first institutions of new Yugoslav authorities, but from the very beginning protected by the Ministry of Culture and eminent Yugoslav historians. The Archives of Yugoslavia today in its depots has 25 kilometers of archival material comprising 859 fonds, 635 out of it belongs to socialistic period. It should be mentioned that outside the Archives, there is 14 kilometers of archival material that haven't been taken over yet of Yugoslav Federal provenience. Besides the Archives of Yugoslavia, archival material from the same creator preserves Ministries of Interior, Exterior and Ministry of Defense. Immense number of kilometers of (mostly) not processed archival material from the very beginning has presented the wall that has stopped any further story about reorganization and unification of archival material of Yugoslav State. Those kilometers require decades of work, hundreds of new employees and always missing funds ${ }^{3}$. Passing the Law on Archives provides possibility to unite complete archival material of Yugoslav provenience into the archive forming thereof first class historical source for writing history of XX century ${ }^{4}$.

At the present situation we can ask ourselves whether accessible archival material in the Archives of Yugoslavia is just the top of the frozen hill of archival documentation. Another question is how much of archival material has been preserved from the period 1990-2006 since according to the law institutions of political parties were not obliged to hand over their archives to the Archives of Yugosla-

\footnotetext{
3. Republic of Serbia does not have Law on Archives so that archival activity is performed according to the law of Federal Republic of Yugoslavia from 1988 where the Archives of Yugoslavia does not exist as institution. In the Bill on Archives and Archival Material that has been waiting more than ten years to be adopted, the Archives of Yugoslavia is defined as institution that protects archival material "formed during the work of central state bodies and organizations of Yugoslav State (1918-2006)."

4. "Federal Executive Council brought the decision of joining all archival services and archives, except military, the Archives of Yugoslavia... this fusion was temporarily postponed so that that decision of FEC was not put in force." Wrote director Dr. Miodrag Zecevic about his work, IN : Arhiv Jugoslavije 1950-2000., p. 49.
} 
via. Archival material of central governmental institutions from this period speaks in favor of our doubt. Every doubt of this kind creates unnecessary feeling that much of it was hidden from "dark" reasons. Experience of decades long work with fonds of central institutions leads into dominant argument that is recognized in non-respecting and ignorance of significance of archival document. Existence of the Law on free access to information (2009) and access to archival material (Data Secrecy Law 2009) confirms our assumptions for unhindered accessibility to federal archival document. That what hinders application of passed laws to open all archives of Yugoslav provenience is lack of the Law on Archives of the Republic of Serbia. Working version of this law assumes joining of archival material created during work of central bodies and organizations. Part of those archives has been handed over to the Archives of Yugoslavia for preservation, but archives of the Ministry of Interior and Exterior Affairs as well as the Ministry of Defense have their own archives completely or partly closed to the public. Accepting technical and other obstacles to have free access to archival material accessible by the law, those archives obeying European Recommendations issue individual and scarce permits to use this documentation for scientific research (ad actum and ad personam) or in some cases if the archival material refers directly to one who requires it. Besides those possibilities the archival material is used for scientific research by the procedure "use of certain parts of documentation" giving just part of a document or the whole document covering protected parts.

Contemporary study of complete Yugoslav history is provided on the first place through accessibility of archival fonds in the Archives of Yugoslavia, where by scientific and critical studying it is possible to have insight to the dealt historical epoch. The Archives of Yugoslavia preserve documentation created by central governmental institutions within relatively short historical period of about seventy (ninety) years but covering turbulent years of XX century with two political-economic systems and with two types of federations.

Inaccessibility of the archival material of Yugoslav provenience that could be possible according to the present laws is one of the reasons that research of communist-socialistic period of Yugoslav state falls behind. The other part of the problem is not for mal but it is regarding contents, it is ideological. If present time presents starting point for the historian to light up the past, scientific researches that helped or did harm to daily politic prevailed and were dominant in official historian science in the past years of all states which cultural heritage has been preserved in the Archives of Yugoslavia. History advances through interpretation of documents and it in that way receives answers regarding past times respectfully helps historian science in "self-perception". Once more, one familiar thesis is confirmed that history is written from the present standpoint since "interest for present life could make someone start researching past and until that all those facts are dead" (Collingwood 2003, $p$. 316). Past times need time distance and after that there would be less value and more factual judgement of joint Yugoslav archives and archival material accessible according to the modern European regulations and would be historians and archivists ready to fight with all scientific challenges.

Past is our heritage although it does not exist anymore we still feel part of it, thinks Geremy Blake. This refers completely to the period of socialistic system that was left by all countries of former Yugoslavia, twenty five years ago, but our emotions towards that time are still strong that "colors" greatly our scientific researches and separates us from rational explanations. Scale of emotions goes from hate to love so compared to the same thoughts the researches themselves are judged as (in)correct. Closeness of socialistic period by the system of coupled historical vessels had great influence to the recent political events so that many scientific attempts remained in the field of so called "Whig History" respectfully politic version of history. History is a science of a special kind, Collingwood assumes, whose business is to study events that were unavailable to our observation and "on the basis of something else that is accessible to our observation and what historian calls "evidence" for the events that he is interested in" (Ibidem, p. 236).

Great disadvantage for historical archives of XX century is missing of that part of the archival document known nowadays as oral history, records of participants of turbulent and very often vague events in the century behind. Neglecting in advance great percentage of the value judgement, statements of participants would give more complex picture of the historic time using value coordinates that many segments of modern social life are based. There was a try to realize this idea upon the proposal of Vladimir Dedijer in the former Archive of Josip Broz Tito immediately after its foundation, 
but it was given up and it haven't come to reality to present day ${ }^{5}$. The time of split history respectfully noncritical history, respectfully idolized reality prevented any thought deferent from official. Now we know how important would be witnessing of the most important participants in Yugoslav authority especially those who "gave up their revolutionary path" for the history of political system. This reality neglected archival material of pre-socialistic provenience by the end eighties and afterwards fonds from socialistic period were behindhand for any kind of processing and at the same time for any research. We are approaching time of critical science and studying of Yugoslav history is yet to come.

Trying to contribute to the development of historical science the Archives of Yugoslavia from the beginning of eighties participated itself in publishing scientific researches performed by the most prominent Yugoslav historians. Scientific commission was formed for this type of activity consisting of well-known university professors that suggested topics and significant publications appeared about the Yugoslav Government in exile, about conversations Tito and Churchill, about organizing of institutions of Yugoslav Federal Government. By the time, the Archives of Yugoslavia relied less on the research work of eminent scientists and more and more published collected papers of already processed archival material mostly for the purpose of everyday politics, most often with directors as editors of publications (Doknić and Petrović 2014, pp. 269-271). In order that future editions of this eminent institution restore its reputation, it is necessary for this kind of activity to form scientific board that would in the interests of science propose long term projects, whose results will contribute to the history of Yugoslav state. Those projects regarding their size could be international including all states that have archival material presenting mutual cultural heritage in the Archives of Yugoslavia ${ }^{6}$. Without responsible scientific board it could happen that the most significant archival material as it is documentation from the cabinet of Josip Broz given irresponsible and in a short-term to one person to inspect having "bang-bang" effect occurs at the news stand next day. The most valuable part of archival documentation is that created in the cabinet of the chief of the state and it should be processed according to the complete arrivistic procedures. It is scientifically valorized, categorized, digitized and only then it could be given for further use, first of all to scientific staff that will confirm significance of such historical source. "Tattering" of this category of archival documentation cause deterioration of archival profession. The Archives of Yugoslavia started to publish its periodical named Bilten in the eighties. This periodical was published until 1986, modest in form but with worthy contents about theory and practice of the archival activity. Periodical Arhiv started in 2000 and it is published depending on funds as double issue once a year, becoming significant place for the young historians and archivists to publish their papers. As part of its scientific research work, the archives of Yugoslavia published Guidebook to fonds. Regarding number of fonds, the guidebook was published in phases. In 2000 upon the fiftieth anniversary of its foundation, The Archives published guidebook through the fonds of the Kingdom of Yugoslavia, three years later, the guidebook to personal collections was published and after ten years of intermission, guidebook to the fonds of central authorities ( president of the republic, parliament and government) with accompanying services. Work on two guidebooks is in progress: guidebook to fonds of the institutions of law and guidebook to the fonds of cultural institutions that would process archival fonds of over 120 federal institutions. Significant number of prefaces written by our eminent historians and political scientists for the need of catalogues for exhibitions has also scientific value.

\section{Research work in the Archives of Yugoslavia}

The Archives of Yugoslavia is inevitable place for a number of scientists, experts and curious persons. Although the number of researchers oscillates in total trend has been increased especially number of researchers from abroad. Fonds stored in the Archives of Yugoslavia are first class historical sources for studying history of Yugoslav state and social and political systems, for studying the country that ceased to exist and political system that vanished, but also for studying the complete XX century. Fonds of central Yugoslav institutions are first and often the least source for studying this historic topic.

5. Vladimir Dedijer, writer of the first Tito's biography, great admirer of archival document was eager to hand over his private archive to the Memorial Center Josip Broz Tito even physical hand over started but since some vague complications it was given up.

6. UNESCO on the basis of its biennial competition has chosen our suggested topic and financed publication of collected papers on Cultural Politics in Yugoslavia 1945-1952. 
The Archive of Yugoslavia has opened its fonds to the public1958. and the first recorded researcher was John Ivo Lederer (SAD) with topic on Versailles Conference in Paris. From that period to 2015 as a result of the work on the Archives fonds, several thousands of doctoral studies were written as well as master thesis, graduation thesis, tents of collections of documents, monographs, articles ${ }^{7}$.

Topics for research (by the insight of Evident) are special cross section of the conditions in the Yugoslav historiography science in the past decades, insight in the part of history undesirable for research work. Even though the Archives of Yugoslavia is public institution, opening of archival fonds to the public has been going slowly and first of all it was opened to the scientists and high officials. The first year when the Archives was open to the public, 11 researchers performed research work there (Lederer Ivo John, Simovski Todor, Rus Joza, Cirkovic Sima, Gros Mirjana, Petranoavic Branko, Vanku Milan, Melik Vasilije, Vuckovic Vojislav with the topics that didn't pass over the time after $1945^{\circ}$. Created as scientific institution, the Archives of Yugoslavia first took over the fonds of Yugoslav institutions that existed in the Kingdom of Yugoslavia and those fonds were accessible to the researchers, the Archives of Yugoslavia was taking over the fonds or part of the fonds from socialistic period, gradually. Fonds of institutions created in socialistic period were completely taken over in the nineties of the last century and they form majority of total archival fond today.

In the coming years the number of researchers was increased, and varieties of research topics were broadening. Ten years later (1968), 75 researchers were recorded (eight scientists from the foreign universities - Sofia, Prague, London, Moscow, Vienna, Rome with the topics dealing with relation between Yugoslavia and Bulgaria, Czechoslovakia, Britain, with National front with Immigrant Government in London, war in Yugoslavia, dealing with the question regarding Rijeka according to the Rome Contract). Yugoslav researchers came from all republics, mostly from capital cities, from universities and faculties. The same year working on the project - monograph Cornicle of Pristina, fonds related to the dealing with situation at Kosovo between the wars ${ }^{9}$ was researched. The greatest part of research referred to the history of communist and labor movement for both the needs of students papers and writing appropriate chrestomathy and monographs ( class struggle, communist movements and upheavals, labor movements, aggressor's crimes, youth work drives, war damage, communists serving long sentence). Cultural history was researched (literacy in Kosovo, Yugoslav literature, film industry).One decade later (1978), the Archives of Yugoslavia visited 201 researchers. There was no foreigners and most researches were done for doctoral and master's thesis ${ }^{10}$. In those papers (only in two of them) scientific researching of socialist historic period started through development of cultural institutions at local level. Ten years later (1988) in the Archives of Yugoslavia, 303 researchers were recorded. Nine of them were from abroad with topics referring to ideology from 1945-1948., regarding the Thessaloniki Process, Curt Waldheim, farming policy 1945-1953. Australian and Canadian embassy employees researched archival material dealing with war crimes, for the trials in Australia and Canada. Domestic researchers were journalists, political workers, architects, retired persons who performed research work in the Archives for professional or personal purposes (family histories, architectural projects, educational system, town in NLM, war sufferings. There were research works in the period after the Second World War in the field of farming policy, socialist association, Yugoslav relation with USA and Great Britain) ${ }^{11}$.

Following decade was time of historical turbulences where communist system disappeared and by disappearance of this ideological glue, Yugoslav state collapsed. Nevertheless year of 1998 was time of all kinds of material and physical insecurity; it was not reflected by the number of research workers

\footnotetext{
7. Publication is printed and brief edition of Evident, data base that is kept in the reading room of the Archives of Yugoslavia, In: Arhiv Jugoslavije: 1950-1995; Korisnici, teme istrazivanja i korisceni fondovi - edition: 1995-1998; $1999-2003$ 2003-2008.

8. Researchers being the young power of Yugoslav historiography only obtained possibility to research and all of them were recorded on January 1, 1958 as the day when they did the research work.

9. Archival documentation created between two world wars in 1968 was used for solving property rights relations in Bosnia and Hercegovina for both institutions and individuals.

10. In the course of 1978 most researchers work for municipalities or institutions on writing festive monographs and chronologies.

11. Upon examination of the list of researched topics it was found out that hundreds of monographs and chronologies of apologetic contents written for special situations and jubilees were published by the end of the nineties. It is disastrous that if hadn't been those monographs, period of Socialist Yugoslavia would have remained completely unexplored.
} 
in the Archives of Yugoslavia. That year recorded 410 researchers, nine of them being from abroad with the topics dealing primarily with the Yugoslav Socialistic political system and international relations. More than seventy scientists (at that time Federation of Serbia and Montenegro) for their topic had certain parts of social and political system and time between 1941 and 1990 that Yugoslav State went through during different stages (Catholic Church, Ustas's crimes, nationalization, collective farms, bilateral relations, student organizations, nonaligned countries, education abroad.

Ten years later in the course of 2008, Archives of Yugoslavia had 419 researchers, 82 of them from abroad. More than half of the topics referred to the time of war and after the Second World War (bilateral relations, education, development of socialism, cultural institutions and institutions of massmedia, war crimes, biographies of politicians, religious congregations, work drives, memorials, international relations). In the year of 2015, 560 individuals were interested in the fonds of the Archive of Yugoslavia, 82 of them were from abroad. As it was the case before, two thirds of them studied period of Yugoslav state before the war and the rest researched the topics referring to political work of Josip Broz, Jovanka Broz, Milovan Djilas, development of socialism and socialistic authorities, nonaligned movement, German reparation, America's aid, construction of New Belgrade, memorials, rock music, cultural connections, political connections, bilateral relations, role of media, cultural institutions, church institutions, Mason's Societies, Jews and their property, censorship, academic migrations, development of sports and sport organizations.

\section{Conclusion}

Historical past is always vague and especially past of a country very often preserved and recognized solely in the archival document. In order to be lighted up from the historic and scientific point of view it is necessary to make accessible to the scientific public historical data in the form of documents. By changing its formal legal status the Archives of Yugoslavia had to change its mode of work without losing its position of historic documentation treasury. On the basis of those documents, thousands of books have been written, scientific papers and gradually and very often from the very beginning, historic epoch that was behind us was lighted up. The Archives of Yugoslavia is in front of organizational changes that are going to modernize this institution and adapt it to high standards in a part of work dealing with scientific research work.

\section{References}

Arhiv Jugoslavije 1950-2000 (2000). Beograd: Arhiv Jugoslavije.

Blejki, D., Makrejld, D. (2007). Izučavanje istorije. Beograd: Clio.

Collingwood, R. (2003). Ideja istorije. Beograd: Sluzbeni list SCG.

Doknić, B. (2003). Arhivska građa kao kulturna baština, In: Arhiv, Arhiv Srbije i Crne Gore, Beograd, n.1/2, pp. 43-48.

Doknić, B. (2009). Uloga arhiviste u instituciji kulturne baštine. In: 8. Tehnični in vsebinski problemi klasičnega in elektronskega arhiviranja, str. 133-139. Maribor: Pokrajinski arhiv.

Doknić, B. (2010). Dostupnost arhivske građe u Arhivu Jugoslavije. In: 9. Tehnični in vsebinski problemi klasičnega in elektonskega arhiviranja, pp. 301-308. Maribor: Pokrajinski arhiv.

Doknić, B., Milic Petrović (2014). Vodic kroz fondove Arhiva Jugoslavije 1945-2006. Beograd: Arhiv Jugoslavije.

Dragićević Šešić, M., Stojković, B. (2011). Kultura. Beograd: Clio.

Ilić, M. (1974). Kultureme. Beograd: Vuk Karadzic.

Korisnici, teme istrazivanja i korišceni fondovi 1995-1998; 1999-2003; Arhiv Jugoslavije, Beograd.

MAS. Strateški pravac 2008-2018 (2008). In: Arhiv, Arhiv Srbije i Crne Gore, n. 1/2, pp. 9-14.

Milošević, M. (1986). Naučna komponenta u arhivskom radu. In: Vjesnik historijskih arhiva u Rijeci i Pazinu, svezak 27.

Tojnbi, A. (2002). Istraživanje istorije. Beograd: CID. 
Zakon o slobodnom pristupu informacijama (Law on Free Access to Information). Službeni glasnik RS, 11.12.2009.

Zakon o tajnosti podataka (Data Secrecy Law). Službeni glasnik RS, 11.12.2009.

\section{SUMMARY}

State gives special attention to the National Archives being institutions that preserve its documentation. This is always one-way relation - to keep the documents as long as possible away from the public that restrains and prolongs scientific research and with the rest of the public it causes confusion and possibility of creating historical mistake. That's the reason why scientific public insists on fast and simple procedure to access archival documentation. Scientific - critical research of Communist - Socialist period is yet to come but without access to whole documentation of Yugoslav provenience it won't be complete. The archival material of the Archives of Yugoslavia is cultural heritage of several European countries and in order that its significance obtains a status of the first class historical source several preconditions should be provided: access to complete archival material of Yugoslav provenience that will be used to prepare precise list or inventory, after that foundation of scientific commission that would deal with scientific valorization and categorization of archival material. Modern approach to the archival material requires new profile of the archivist. Within present archival profiles, the Archives of Yugoslavia should form scientific department. Only scientifically educated archivist would be able to decide according to the achievements of the social science about significance of the archival material and its cultural value, priority in preservation and as well be of the greatest help to the researchers who come to the Archives.

Typology: 1.04 Professional Article

Submitting date: 29.01 .2016

Acceptanca date: 20.02 .2016 